\title{
IMPLEMENTATION OF PROBLEM-BASED LEARNING TO IMPROVE PROBLEM-SOLVING SKILLS IN VOCATIONAL HIGH SCHOOL
}

\author{
Reny Murni Hidayati ${ }^{1 *}$, Wagiran ${ }^{1}$ \\ ${ }^{1}$ Universitas Negeri Yogyakarta \\ Jl. Colombo No. 1, Karangmalang, Depok, Sleman, Yogyakarta 55281, Indonesia
}

\begin{abstract}
The learning process in Vocational High Schools must encourage students to have problem-solving skills needed in the industry through the application of appropriate learning models. In reality, the students' problem-solving skills in computer subjects and basic networks are still lacking, and the Problem-Based Learning learning model has never been applied. This research aims to understand the implementation of Problem-Based Learning (PBL) to improve students' problem-solving skills. This research is a class action research model of Kemmis and Taggart, carried out in three cycles; each cycle consisted of two meetings. The data were analyzed descriptively. The results show how $P B L$ on computer subjects and basic networks can improve problem-solving skills. Improvements occurred in all aspects of observation. In problem-solving skills, $56.25 \%$ of the students in the above medium category in cycle I increased in cycle II to be $71.875 \%$ and increased again in cycle III to be $100 \%$. This means that there are no students below the medium category in cycle III. PBL can improve problem-solving skills with the steps: (1) orienting students to the problem classically; (2) organizing students to study in a group work of four people and the division of tasks for each member; (3) guiding individual and group investigations on the same topic, discussed maximum in two groups; (4) developing and presenting the work done in front of the class with more time allocation in the discussion session; (5) analyzing and evaluating the problem-solving process that focuses on re-checking the results.
\end{abstract}

Keywords: problem-solving skills, problem-based learning, vocational high school

How to cite: Hidayati, R., \& Wagiran, W. (2020). Implementation of problem-based learning to improve problem-solving skills in vocational high school. Jurnal Pendidikan Vokasi, 10(2), 177-187. doi:https://doi.org/10.21831/jpv.v10i2.31210

*Corresponding Author: Reny Murni Hidayati reny.mh24@gmail.com

Department of Technology and Vocational Education, Graduate School, Universitas Negeri Yogyakarta

Jl. Colombo No. 1, Karangmalang, Depok, Sleman, Yogyakarta 55281, Indonesia 


\section{INTRODUCTION}

The needs and challenges of the increasingly complex world of work require graduates to be able to compete and have professional competencies. The world of work will require the workforce to have the ability to think at a high level, problem-solving and collaborative learning. This is supported by several studies on learning outcomes to deal with the world of work. $21^{\text {st }}$ century skills and attitudes are classified as ways to think (knowledge, critical and creative thinking), ways to learn (literacy and soft skills), and ways to learn with others (personal, social, and civic responsibilities) (Griffin \& Care, 2015). To enter the "new world of work" seven survival skills are required, namely: (1) critical thinking and problem-solving; (2) collaboration across networks and leading by influence; (3) agility and adaptability; (4) initiative and entrepreneurialism; (5) effective oral and written communication; (6) accessing and analyzing information; (7) curiosity and imagination (Wagner, 2008, p. 14). There is a paradigm shift and $21^{\text {st }}$ century competency framework regarding $21^{\text {st }}$ century student outcomes and support systems formulated in The Partnership for 21st Century Skills, where $21^{\text {st }}$ century student outcomes include learning and innovation skills which include creativity and innovation skills, critical thinking and problem-solving skills, communication and collaboration skills (Partnership for 21st Century Skills, 2008).

One of the Educational Institutions whose job to produce a competent workforce is Vocational Education. In Indonesia there are three levels of Vocational Education namely at the level of vocational secondary education, vocational education in higher education, and professional education. The success of Technical and Vocational Education and Training (TVET) is measured from four aspects, namely: (1) the degree of absorption of graduates in the world of work; (2) alumni satisfaction level after completing Education; (3) the level of alumni user satisfaction with alumni performance in the world of work; (4) the number of alumni as entrepreneurs (Sudira, 2018, p. 6). Vocational High Schools as one of the Vocational Education Institutions at the secondary level must be able to produce competent graduates so that the success of TVET is achieved.

The quality of vocational high school graduates is influenced by several factors, one of which is the quality of the learning process in schools. To achieve the competency needed in the working world in the 21st century, learning in vocational high schools must be able to encourage students to be creative and innovative, to think critically to solve problems, and to have the ability to communicate and collaborate. In addition, learning in vocational high schools must also be able to fulfill the needs of work skills in the 21st century which are quite complex and lead to the skill of using High Order Thinking Skills (HOTS). The learning process in vocational high school should also by folowing the needs in the industrial world. Therefore, subjects given during learning should refer to industry needs.

Vocational Basic subjects are the basic subjects for Teknik Komputer dan Jaringan (TKJ) / Computer and Network Engineering major, meaning that Vocational Basic subjects will comprehensively underlying TKJ graduates. Mastery of basic vocational learning materials is very important because it is the basis for understanding, knowing, and having the next competence in stages.

However, as the matter of fact, based on alumni tracking by schools, students start to work between three months until one year, but students who work according to vocational school competency skills are only 10\%. Based on interviews conducted with alumni, the level of problemsolving creativity that applied in learning with demands in world of work is rather not optimal.

Based on the interview with students, TKJ subjects are difficult to understand in practical steps. Most students claimed to have difficulty in applying the theory that has been learned into practice. Students are less-able to construct the theories that have been learned into practice. In addition, based on the researchers' observations during learning, students are less enthusiastic about learning because learning is still dominated by teachers. However, when students are asked for discussion and the teacher gave stimulus questions to the students to develop their curiosity, students look silent and only rely on one of the friends from the group. Students are less able to understand the problems given so it is difficult to solve the problems.

The lack of variations in learning models and limited facilities and infrastructure cause students to be less active in giving opinion. Students are not yet having an awareness that learning is their need. At the time of learning process, students secretly use smartphones or computers for un- 
necessary purposes. In addition, students have the habit of skipping school so that the understanding of the material is different from one student to another. This causes the ability to solve problem of students is not visible.

Teachers as educators have the task and responsibility of finding appropriate learning models in implementing learning to improve students' creative thinking and problem-solving. The use of varied learning methods and student center will foster creativity and problem-solving skill in learning. The learning models applied must also meet the needs of conformity to the work context. Various learning models are suitable to be applied, one of which is the problem-based learning model (PBL) (Sudira, 2018, p. 157).

PBL is one of the right models developed in learning to respond to the issue of improving the quality of learning and anticipating changes in the working world (Nurhadiyanto \& Wagiran, 2007, p. 13). PBL learning model provides a positive influence in order to improve problem solving, critical thinking, and creativity (Selçuk et al., 2013). Therefore, it is believed that PBL can improve problem-solving skills through the process of understanding the context of real-world problems and then constructing them in practical learning activities.

Several studies have been conducted including research on mathematics students (tenth-year senior high school) which states that PBL can improve problem-solving skills (S. J. Simamora et al., 2017). Implementation of PBL Models can improve students' problem-solving and self-efficacy on IX Class Students of Muhammadiyah Junior High School (Rokhmawati et al., 2016). PBL can also enhance learning activities and problem-solving skills of junior high school students (R. E. Simamora et al., 2017). Besides, the use of PBL is as an effective instructional tool to improve problem-solving skills at the undergraduate level (Kadir et al., 2016). Based on the real conditions or problems in the classroom and the previous research studies, it is necessary to research to improve students' problem-solving skills using PBL in the vocational high school level.

\section{Problem-Solving Skill}

Problem-solving is a strategic competency shown by students in understanding, choosing approaches and problem-solving strategies, and solving models to solve problems (Regulation of the Minister of National Education of Republic of Indonesia No. 22 of 2006). In addition, Gagne also stated that the ability to solve problems is a set of procedures or strategies that enable one to increase independence in thinking (Amir, 2009, p. 45). In developing problem-solving competencies, between learning content and problem-solving competencies, it is unnecessary to be carried out in different activities, so that interrelated activities can achieve goals in learning (Yeo \& Tan, 2014, p. 747). Hence, in practice, learning with PBL in it can contain problem-solving content.

According to Polya, there are five steps in problem-solving that can be observed, namely, the ability to: (1) understand the problem (understanding), (2) plan solutions (planning), (3) solve problems (solving), and (4) do the re-checking (checking) (Nuralam, 2009). These steps were used as indicators of observing the ability of problem-solving.

\section{Problem-Based Learning Model}

Problem-based learning is a learning model that uses real problems (authentic) that are not structured (ill-structured) and is open as a context for students to develop problem-solving skills and critical thinking and build new knowledge (H. Sofyan et al., 2016, p. 25). In line with this, Dutch added that PBL is an instructional method that challenges students to learn to work together in groups and find solutions to the real problems (Amir, 2009, p. 27). Based on those opinions, it can be concluded that PBL is a learning approach based on real problems to develop problemsolving skills and build new knowledge.

PBL offers teachers a structured method that helps students to develop thinking and problem-solving skills while students master important basic knowledge subject (Delisle, 1997, p. 5). In the implementation of PBL, it is very important to emphasize that PBL is learning in harmony with important scientific learning, stressed Sofyan and Komariah (2016, p. 269). PBL encourages students to find new solutions to the problems presented. Students use various sources of information from their textbooks and others in informal discussions with peers (Major \& Palmer, 2001). In the 
process, it is believed that it can improve problem-solving skills creatively. Groups involved in PBL practice develop creative thinking by brainstorming when making hypotheses, creating new ways, and integrating skills in a variety of learning material content (Susanti et al., 2016). Students work in small groups to bring together collective skills in acquiring, communicating, and producing information to produce thinking skills, able to analyze and solve complex real-world problems (Duch et al., 2001, p. 6). Although students find learning through PBL is difficult, they are thinking more than memorizing (Awang \& Ramly, 2008). This means, PBL can help students understand the problem, plan problem-solving, and solve problems. In large classroom settings, PBL methodology also has a positive effect on students' problem-solving skills (Klegeris \& Hurren, 2011).

PBL also has several weaknesses. One of them is when the students have no interest to the problem that will be solved, they will not be eager to try. Besides, when some students assumed that the problem solved is not beneficial, they will study on their own way. The implementation of problem-based learning also requires quite a long time, a standard of 40 to 50 minutes for one lesson at school (Sanjaya, 2009, p. 68).

There are five phases in implementing PBL: (1) orienting students on the problem; (2) organizing students to research; (3) helping independent investigation and communication; (4) developing and presenting the work; (5) analyzing and evaluating the process of solving problems, problems in cyberspace involving learning (Arends, 2008, p. 55). These steps were used in conducting this research. From the description, it can be seen that learning with PBL can be applied as a learning model that can improve problem-solving skills. Thus, it is expected that problem-solving skills can be improved by Problem-Based Learning (PBL) model.

\section{RESEARCH METHOD}

The type of research used is classroom action research that aims to overcome the problems found in the classroom. Classroom action research uses Kemmis and Taggart's model. The research was conducted in three cycles, each meeting consisting of three stages: Action Plan, Actuating and Observing, and Reflecting. The action and observation stages are merged because they are two inseparable actions (McTaggart, 1994, p. 31). Visually, the stages of each cycle are presented in Figure 1.

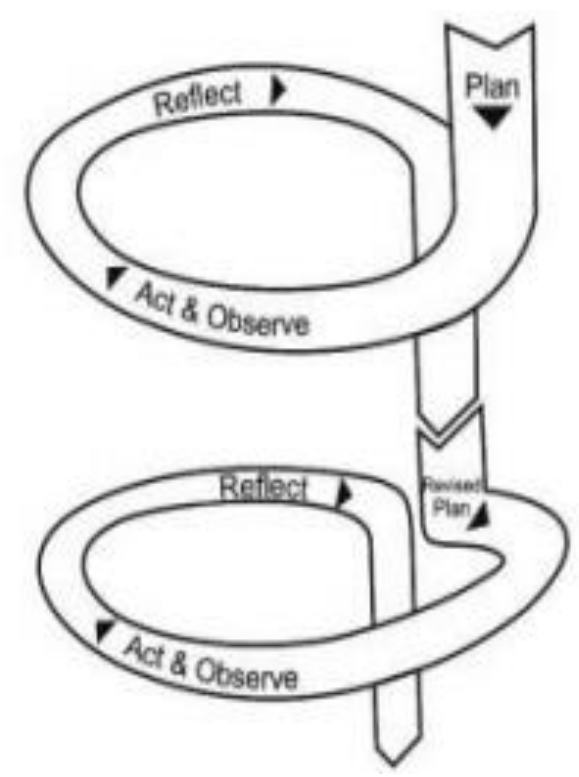

Figure 1. PTK Cycle According to Kemmis and Mc. Taggart

\section{Research Setting}

The research was conducted in three months, from January to April 2018. The research was conducted in a vocational school located in Bantul, Yogyakarta. 


\section{Subjects and Characteristics}

The subject of this research was TKJ grade $\mathrm{X}$ students, the participants are 32 students who carried out learning activities in the even semester of computer and basic network subject in 2017/ 2018 academic year. The reason for taking the subject of the research is because the class has several issues with the problem-solving skills in learning both theory and practice.

\section{Action Scenarios}

The research was carried out in a participatory and collaborative way. It is participatory because the researchers were directly involved in all stages of the study. It is collaborative because it involved the teacher as the observer in the research. The planning stage is planned based on pre cycle. Activities undertaken include: (1) preparing of lesson plans; (2) preparing a learning scenario; (3) preparing learning media; (4) preparing discussion material and questions; (5) preparing observation sheets.

The actuation phase is the application of the lesson plan which is divided into preliminary activities, main activities, and closing activities. Preliminary activities include: greeting, conditioning students, leading prayers, calling roll, explaining about PBL, motivating, delivering learning objectives, appreciating. The main activities include activities using a problem-based learning model consisting of five stages: (1) orienting students towards the problem; (2) organizing students to learn; (3) guiding individual and group investigations; (4) developing and presenting the work; (5) analyzing and evaluating the problem-solving process. Closing activities include: reflecting (drawing conclusions, delivering future activities, praying, and greeting). The observation phase was carried out during the teaching and learning process. The observation was made on the learning activities of students in the learning process, namely observation to the ability to think creatively and problem-solving. The reflection phase was done after the teaching and learning process completed. The researchers and the collaborator team summarized the successes and weaknesses of each meeting. The weaknesses functioned to improve the next cycle.

\section{Data Collection Techniques and Instruments}

The techniques used to collect data were observation, documentation, and field notes. Observation was used to reveal changes in behavior during research related to problem-solving skills. Documentation and field notes were used to record the activities during the research. The instrument used to measure the ability to think creatively and problem-solving using observation sheets using a rating scale where this type gives numbers in the aspects of assessment columns with limited classification. The assessment aspects will be given a number from 1 to 4 .

\section{Success and Data Analysis Techniques}

Teaching and learning process is said to be successful and has a good quality if all or at least $75 \%$ of the students from the class are capable of solving problems in medium category. Data analysis used for the problem-solving skills is a descriptive analysis based on the observation sheet. Data from the observation were analyzed and presented in the form of percentages and interpreted in words. The problem-solving skills value of each student in each indicator is processed by adding up the scores obtained to determine the total value of the problem-solving skill of each indicator and each student, then comparing it with the expected maximum score. After students' grades are obtained, those grades are then grouped into five levels of problem-solving skills (Table 1).

Table 1. Level of Problem-solving Skills

\begin{tabular}{cc}
\hline Degree of Problem-Solving Skills & Category of Problem-Solving Skills \\
\hline $90-100$ & Very High \\
$80-89$ & High \\
$65-79$ & Medium \\
$55-64$ & Low \\
$0-54$ & Very Low \\
\hline
\end{tabular}


The percentage of problem-solving skills was calculated using Formula (1). The observation guidelines used to measure the students' problem-solving skills during the teaching and learning process is presented in Table 2 .

Problem solving precentage $=\frac{\sum \text { score obtained by student }}{\text { maximum score of each aspect }} \times 100 \%$

Table 2. Observation Guideline of Problem-Solving Skills

\begin{tabular}{cll}
\hline No & Indicator & \multicolumn{1}{c}{ Criteria } \\
\hline 1 & Understanding & $\begin{array}{l}\text { Able to interpret problems by mentioning what is understood and asked. } \\
\text { Able to make a plan to solve the problem based on the procedure using the } \\
\text { right solving steps and relate the concept. }\end{array}$ \\
& Planning & $\begin{array}{l}\text { Able to do steps to solve the problem using the procedure in a detail way. } \\
\text { Able to check carefully to prove the process validity. }\end{array}$ \\
\hline
\end{tabular}

\section{RESULTS AND DISCUSSION}

This classroom action research began with pre-action activities. Pre-action activities were carried out to determine the initial abilities of the students. Based on preliminary observations regarding aspects of problem-solving skills, $50 \%$ of the students show problem-solving skills in low category. The students had not written in detail the flow of problem-solving and do not re-check the tasks given. In detail, the results of initial observations of students are presented in Table 3.

Table 3. Results of Preliminary Observations of Problem-Solving Skills

\begin{tabular}{|c|c|c|c|}
\hline Degree of Problem-Solving Skills & Category of Problem-solving Skills & $\begin{array}{c}\text { Number of } \\
\text { Student }\end{array}$ & $\begin{array}{c}\text { Percentage } \\
(\%)\end{array}$ \\
\hline $90-100$ & Very High & 0 & 0 \\
\hline $80-89$ & High & 1 & 3.125 \\
\hline $65-79$ & Medium & 8 & 25.00 \\
\hline $55-64$ & Low & 16 & 50.00 \\
\hline \multirow{2}{*}{\multicolumn{2}{|c|}{ Very low }} & 7 & 21.875 \\
\hline & & 32 & 100 \\
\hline
\end{tabular}

In the preliminary activities, teachers and students prayed together as a form of self-actualization to the spiritual attitude. The teacher also called the roll to check students' attendance. The students were given ice breaking guided by the teacher to help them focus on learning. They were also given the reading material related to the material to be taught. The time allocation was written in front of the class so the students could estimate the time to solve the problem. The teacher informed that the teaching and learning proccess used PBL model which conveys learning objectives and provides apperception. At the main activity, PBL that has been integrated with a scientific approach was carried out. The stages of PBL to improve problem-solving in detail are as follows.

The first stage is orienting the students to the problem classically. The teacher is given the reading material related to the material, lets the students to observe, understand the problem, and express relevant ideas. They ask the students to find out students' understanding of the problem, and provide score for the students who dare to express their ideas. Classically, the teacher introduces the topic of learning and provides problems for each group to be solved later.

The second stage is organizing the students to study. The students are divided into four heterogeneous groups. The success of the group is very important. The students divide roles into groups including leading discussions and practices, recording results, reporting to the class, and checking the accuracy. This is in line with Duch et al. (2001) that small groups can unite collective skills so they can analyze and solve problems. The teacher gives worksheets and walks around to help the students identify what needs to be done and found in practice. The students understand the problem given (write down what is known and asked). The students read worksheets and explore supporting information such as in the internet and books. Student divided into study groups of four people and worksheet as a medium, it provides a more meaningful experience (S. J. Simamora et al., 2017). 
The third stage is guiding individual and group investigations. The students prepare equipment and materials according to the instructions, discuss them to solve problems given. Every two groups discuss the same material, this has proven to be more effective. The students arrange the steps for problem-solving in detail, carry out practical activities, and write down the results of the practice in detail and other possibilities in the problem-solving process. Practical activities are still being started from the basic skills to the competencies to be achieved. Repetition of practice to make the students are well trained. The teacher goes around monitoring the work of the students and provides an assessment of individual skills.

The fourth stage is developing and presenting the work. Group representatives present practice reports and discussion results. Other groups must express their opinions and express different concepts or findings. This stage is carried out in classical class. More time is allocated for question and answer sessions. The teacher also provides stimulus so that the students can express concepts that have not been revealed in their own words.

The fifth stage is analyzing and evaluating the problem-solving process. Classically, the teacher reviewsed what has been presented and evaluates the teaching and learning process in class. The students would pay their attention and checked the work results of each group. At the end of the activity, the students return the equipment.

In the closing activity, the teacher and students conclude the material that has been learned, give homework, and give a closing greeting. With activities like the above stages can improve the students' skill to think creatively and problem-solving.

The improvement of the learning atmosphere of the first cycle, second cycle, and third cycle are as follows. In the first cycle, many students were late coming to the class so that it disturbed the concentration of other students. Based on the field notes, the lateness of the students was between 10 to 30 minutes. Some students did not bring books and were not disciplined in wearing uniforms. Students were also not familiar with PBL, so the students claimed that this stage was difficult. The students tended to be passive and repeated the answers of their friends when being asked to express ideas by the teacher. The atmosphere of the class seemed noisy because during the discussion the students asked one another between groups. In the practice activities, the students worked alternately and passively. Different discussion materials each group provided diversity, but the students did not listen to the results of other group discussions so that the mastery of the material is not well achieved. In the presentation, the students tended to memorize and less active. The students were not yet aware of the urgency of learning.

The condition gradually improves in cycle II where the lateness was decrease. In this second cycle, ice breaking began to be given to practice focus and motoric movement. The allocation of the learning time was written in front of the class by the teacher. The students were getting used to PBL rules. The students used to express ideas. Additional points were given to the students who expressed ideas in a relevant way so that the students were enthusiastic. The students positioned themselves in an orderly manner in their respective groups according to the assigned tasks division. Teaching and learning process were more conducive. There were still some groups that asked the teacher to solve the problems. The students began to be detail in writing problem-solving. However, in the presentation, the students paid less attention because the discussion of the presentation between one group and the other was the same. The process of analyzing and evaluating problemsolving run smoothly and there was a two-way communication between the students and the teacher. There were still some students who tried to cheat when they took the test. The students complained when they were given homework. The activities in cycle II were improved in cycle III.

In cycle III, there were no students who came late to the class and dressed according to the rules. Ice breaking activities were carried out under the direct guidance of the teacher. The reading material provided was proven to be more effective because the students were more focused on reading. This is in accordance with a research conducted by Major and Palmer (2001) that the use of various sources of information and informal discussions with peers is more effective. The students actively expressed ideas then the teacher gave points and responds. The atmosphere is calm during the process. The students positioned themselves according to the group calmly. The teacher goes around helping the students identify the problems. The students looked for references from worksheets and the internet. The students worked together in accordance with the division of tasks 
that had been given. The work was completed faster. Although at the beginning of learning students complained that it was difficult, at the end of the cycle the students can complete the work with better results. This is because the students think more than memorizing (Awang \& Ramly, 2008). At the end of the practice, the teacher evaluated the group work. Group representatives presented the results and conducted question and answer classically. In this session, the time allocation was longer. At the stage of analyzing and evaluating the problem-solving process, each group member paid attention to the teacher and re-checked the results of the discussion and practice. At the end of the meeting, the students worked on the test calmly and did not do cheating. In detail, the development process of each cycle is illustrated in Table 4.

Table 4. Description of Student Development in Cycle I, Cycle II, and Cycle III

\begin{tabular}{|c|c|c|c|}
\hline PBL Process & Cycle I & Cycle II & Cycle III \\
\hline $\begin{array}{l}\text { Stage 1: } \\
\text { Orienting } \\
\text { students to } \\
\text { the problem }\end{array}$ & $\begin{array}{l}\text { Students started to pay at- } \\
\text { tention to the topic given. } \\
\text { They were still lack of the } \\
\text { understanding of the } \\
\text { problem. Few students } \\
\text { could express ideas. }\end{array}$ & $\begin{array}{l}\text { Students were used to PBL, fo- } \\
\text { cused in teaching and learn-ing } \\
\text { process, showed problem un- } \\
\text { derstanding classically better } \\
\text { than in the previous cycle. }\end{array}$ & $\begin{array}{l}\text { Conducive class from the be- } \\
\text { ginning. Point given made the } \\
\text { students to try to understand the } \\
\text { case given so they could ex- } \\
\text { press relevant ideas. It was } \\
\text { done classically in the class. }\end{array}$ \\
\hline $\begin{array}{l}\text { Stage 2: } \\
\text { Orienting the } \\
\text { students to } \\
\text { study }\end{array}$ & $\begin{array}{l}\text { Students tended to be } \\
\text { noisy when setting } \\
\text { groups. Only one student } \\
\text { actively looked for the in- } \\
\text { formation. The coopera- } \\
\text { tion in a group was not } \\
\text { good. }\end{array}$ & $\begin{array}{l}\text { There was task division for } \\
\text { each member. Students could } \\
\text { explore information from } \\
\text { worksheets and from the inter- } \\
\text { net. They started to write down } \\
\text { what they knew and what was } \\
\text { asked in not too detail way. }\end{array}$ & $\begin{array}{l}\text { Task division of each member } \\
\text { ran more effective. All students } \\
\text { were involved in understanding } \\
\text { problems. They could write } \\
\text { what they knew and what was } \\
\text { asked in a more detail way than } \\
\text { before. }\end{array}$ \\
\hline $\begin{array}{l}\text { Stage } 3 \text { : } \\
\text { Guiding } \\
\text { investigation } \\
\text { both } \\
\text { individual } \\
\text { and group }\end{array}$ & $\begin{array}{l}\text { The class was noisy. The } \\
\text { students were passive in } \\
\text { discussion. They started } \\
\text { to plan problem-solving } \\
\text { but not that in detail. } \\
\text { Some students did trou- } \\
\text { bleshooting without ask- } \\
\text { ing to the teacher first. }\end{array}$ & $\begin{array}{l}\text { In practice, the students } \\
\text { worked alternately, the others } \\
\text { did nothing. More in detail in } \\
\text { planning problem-solving. } \\
\text { More students solved problems } \\
\text { and did trouble-shooting with- } \\
\text { out asking the teacher. }\end{array}$ & $\begin{array}{l}\text { Group work worked well ac- } \\
\text { cording to the main task divi- } \\
\text { sion and they help one another. } \\
\text { The students were able to plan } \\
\text { problem-solving in detail and } \\
\text { did problem-solving process } \\
\text { correctly. }\end{array}$ \\
\hline $\begin{array}{l}\text { Stage 4: } \\
\text { Developing } \\
\text { and } \\
\text { presenting } \\
\text { work }\end{array}$ & $\begin{array}{l}\text { In writing down the re- } \\
\text { sults of the discussion, } \\
\text { students just memorize. } \\
\text { The mate-rial was differ- } \\
\text { ent for each group, mak- } \\
\text { ing the group that did not } \\
\text { pay enough attention to } \\
\text { be less in understanding } \\
\text { the material. }\end{array}$ & $\begin{array}{l}\text { The result was presented by } \\
\text { each group. The material pro- } \\
\text { vided was the same so that in } \\
\text { the middle to the end of time } \\
\text { the students did not pay atten- } \\
\text { tion. The students checked the } \\
\text { stage of problem-solving }\end{array}$ & $\begin{array}{l}\text { The result was presented by } \\
\text { group representatives to save } \\
\text { time and more time was given } \\
\text { in the discussion of the mate- } \\
\text { rial. Other group members were } \\
\text { required to ask questions and } \\
\text { express opinions while check- } \\
\text { ing the stage of problem-solv- } \\
\text { ing. }\end{array}$ \\
\hline $\begin{array}{l}\text { Stage 5: } \\
\text { Analyzing } \\
\text { and } \\
\text { evaluating } \\
\text { problem- } \\
\text { solving } \\
\text { process }\end{array}$ & $\begin{array}{l}\text { Re-checking the results of } \\
\text { the practice found that } \\
\text { some groups were not op- } \\
\text { timal in solving the prob- } \\
\text { lem. At the time of the } \\
\text { test there were many stu- } \\
\text { dents who cheated. }\end{array}$ & $\begin{array}{l}\text { The group that checked the re- } \\
\text { sults of the practice more than } \\
\text { the previous cycle, but not all } \\
\text { of them did it in detail. }\end{array}$ & $\begin{array}{l}\text { Students had checked the com- } \\
\text { pletion step. Students provided } \\
\text { feedback on the evaluation of } \\
\text { the problem-solving process by } \\
\text { the teacher. }\end{array}$ \\
\hline
\end{tabular}

With problem based learning (PBL) and improvements in each cycle in a large class setting, problem-solving skills can be improved. This is in accordance with a research which was conducted by Klegeris and Hurren (2011) that the methodology has a positive effect in solving problems in large classes. The use of problem based learnig has been proven to be effective in improving the problem-solving abilities (Kadir et al., 2016; Rokhmawati et al., 2016; R. E. Simamora et al., 2017). Table 5 presents the detail of the values in the aspect of observation of the problem-solving skills. 
185 - Reny Murni Hidayati \& Wagiran

doi $_{\text {https://doi.org/10.21831/jpv.v10i2.31210 }}$

Table 5. Recapitulation of Problem-Solving Skills

\begin{tabular}{|c|c|c|c|c|c|c|c|c|c|c|c|c|c|}
\hline \multirow{2}{*}{$\begin{array}{c}\text { Degree } \\
\text { of } \\
\text { Problem- } \\
\text { Solving } \\
\text { Skills }\end{array}$} & \multirow{2}{*}{$\begin{array}{c}\text { Category } \\
\text { of } \\
\text { Problem- } \\
\text { solving } \\
\text { Skills }\end{array}$} & \multicolumn{2}{|c|}{$\begin{array}{c}\text { Cycle I } \\
\text { meeting 1 }\end{array}$} & \multicolumn{2}{|c|}{$\begin{array}{c}\text { Cycle I } \\
\text { meeting } 2 \\
\end{array}$} & \multicolumn{2}{|c|}{$\begin{array}{c}\text { Cycle II } \\
\text { meeting } 1 \\
\end{array}$} & \multicolumn{2}{|c|}{$\begin{array}{c}\text { Cycle II } \\
\text { meeting } 2\end{array}$} & \multicolumn{2}{|c|}{$\begin{array}{c}\text { Cycle III } \\
\text { meeting } 1\end{array}$} & \multicolumn{2}{|c|}{$\begin{array}{c}\text { Cycle III } \\
\text { meeting } 2\end{array}$} \\
\hline & & $\sum$ & $\%$ & $\sum$ & $\%$ & $\sum$ & $\%$ & $\sum$ & $\%$ & $\sum$ & $\%$ & $\sum$ & $\%$ \\
\hline $90-100$ & Very High & 0 & 0 & 0 & 0 & 4 & 12.50 & 4 & 12.5 & 5 & 15.625 & 5 & 15.625 \\
\hline $80-89$ & High & 2 & 6.25 & 5 & 15.625 & 5 & 15.625 & 12 & 37.50 & 10 & 31.25 & 11 & 34.375 \\
\hline $65-79$ & Medium & 10 & 31.25 & 13 & 40.625 & 13 & 40.625 & 7 & 21.875 & 9 & 28.125 & 16 & 50.00 \\
\hline $55-64$ & Low & 17 & 53.125 & 12 & 37.50 & 10 & 31.25 & 9 & 28.125 & 8 & 25.00 & 0 & 0 \\
\hline $0-54$ & Very low & 3 & 9.375 & 2 & 6.25 & 0 & 0 & 0 & 0 & 0 & 0 & 0 & 0 \\
\hline \multicolumn{2}{|c|}{ Sum } & 32 & 100 & 32 & 100 & 32 & 100 & 32 & 100 & 32 & 100 & 32 & 100 \\
\hline
\end{tabular}

Based on the observation, it was obtained the results in the first cycle, most of the students were at a medium level with a percentage of $40.625 \%$. There were already five students at a high level with a percentage of $15.625 \%$. However, there were still many of them who were at a low level with a percentage of $37.5 \%$ and very low with a percentage of $6.25 \%$. This was increased in Cycle 2. There were four students in a very high level with a percentage of $12.5 \%, 12$ students in a high level with a percentage of $37.50 \%$, seven students at a medium level with a percentage of $21.875 \%$, eight students at the low level and none student at the very low level. It is increased again in Cycle III, at the medium level there were 16 students with a percentage of $50 \%$. High level was $34.375 \%$, and a very high level was $15.625 \%$. In this third cycle, there are no students in the low and very low categories. The improvement of the problem-solving skills in every aspect is shown in the recapitulation graph of problem-solving skills of cycles I, II, and III illustrated in Table 6 and Figure 2.

Table 6. Percentage of Appearance Indicators of Problem-Solving Skills

\begin{tabular}{cccccccc}
\hline & & \multicolumn{2}{c}{ CYCLE I } & \multicolumn{2}{c}{ CYCLE II } & \multicolumn{2}{c}{ CYCLE III } \\
\cline { 3 - 7 } No & Indicator of Problem-Solving Skills & Meeting & Meeting & Meeting & Meeting & Meeting & Meeting \\
& & $\mathbf{1}$ & $\mathbf{2}$ & $\mathbf{1}$ & $\mathbf{2}$ & $\mathbf{1}$ & $\mathbf{2}$ \\
\hline 1 & Understanding & 72.46 & 74.41 & 78.71 & 88.48 & 87.30 & 87.30 \\
2 & Planning & 64.06 & 69.73 & 76.37 & 77.73 & 78.32 & 78.52 \\
3 & Solving & 61.72 & 71.48 & 72.27 & 76.17 & 79.49 & 79.69 \\
4 & Checking & 53.91 & 67.97 & 71.48 & 72.85 & 74.80 & 77.15 \\
\hline
\end{tabular}

\section{Percentage of Appearance Indicator of Problem Solving Skills in Cycle I, Cycle II, Cycle III}

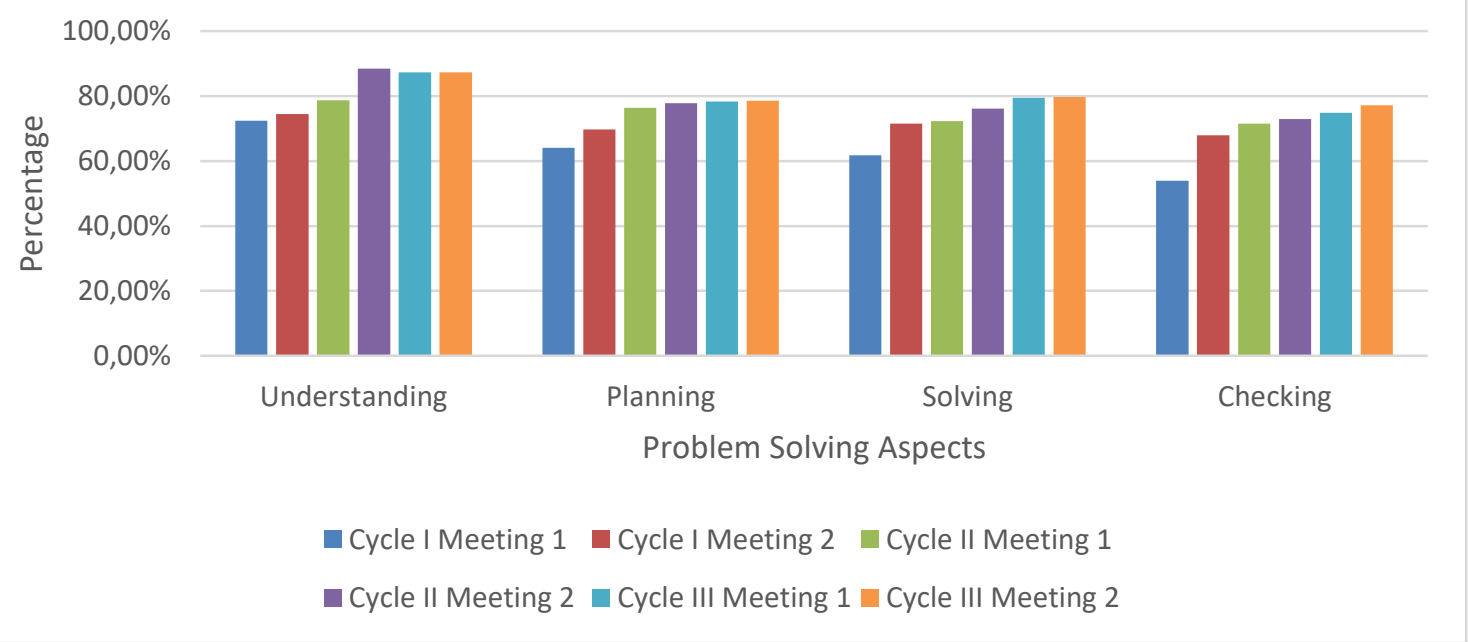

Figure 2. Recapitulation Graph of Problem-solving Skills in Cycle I, II, and III 


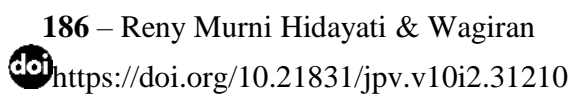

From the results of observing the skills of problem-solving, all aspects of problem-solving skills have reached the criteria of research success that minimum $75 \%$ of students in medium level. Thus, learning by using PBL can improve students' problem-solving skills.

\section{CONCLUSION}

The implementation of teaching and learning process in Computer and Basic Network subject by using PBL in class X TKJ at a vocational high school can improve problem-solving skills. The stages done are orienting the students to the problem classically, organizing the students to study in groups of four people and the division of tasks turns out to be more effective, guiding individual and group investigations (effective if each two groups discuss the same material), developing and presenting the work done in front of the class with more time allocation, analyzing and evaluating the problem-solving process that focuses on re-checking the results. It can be proven by increasing the activity of each cycle and has achieved indicators of research success. In problemsolving skills, there were $56.25 \%$ of the students who were in the above medium category in cycle I. Increased in cycle II to be $71.875 \%$ and increased again in cycle III to be $100 \%$. This means that there are no students below the medium category in cycle III.

Based on the results and conclusions, some suggestions can be given, among others: for teachers who want to implement learning process, they should plan it well and use the time allocation well. Good time management can help students in completing each stage of learning according to a predetermined time limit. For schools, it is expected to provide full evaluation and support for teachers to develop a variety of learning models in the classroom so that the learning process can run well. And for researchers, it is expected to be able to apply PBL in learning in larger classes and longer periods so that the results are possible to be generalized.

\section{REFERENCES}

Amir, M. T. (2009). Inovasi pendidikan melalui problem based learning. Kencana Prenada Media Group.

Arends, R. I. (2008). Belajar untuk mengajar (H. P. Soetjipto \& S. M. Soetjipto (Trans.)). McGraw Hill.

Awang, H., \& Ramly, I. (2008). Creative thinking skill approach through problem-based learning: Pedagogy and practice in the engineering classroom. International Scholarly and Scientific Research \& Innovation, 2(4), 334-339. https://doi.org/10.5281/zenodo.1084906

Delisle, R. (1997). How to use problem-based learning in the classroom. ASCD.

Duch, B. J., Groh, S. E., \& Allen, D. E. (Eds.). (2001). The power of problem based learning: A practical "how to" for teaching undergraduate courses in any discipline. Stylus Publishing.

Griffin, P., \& Care, E. (2015). Assesment and teaching of 21st century skills: Methods and approach. Springer.

Kadir, Z. A., Abdullah, N. H., Anthony, E., Salleh, B. M., \& Kamarulzaman, R. (2016). Does problem-based learning improve problem solving skills?-A study among business undergraduates at Malaysian premier technical university. International Education Studies, 9(5), 166-172. https://doi.org/10.5539/ies.v9n5p166

Klegeris, A., \& Hurren, H. (2011). Impact of problem-based learning in a large classroom setting: Student perception and problem-solving skills. Advances in Physiology Education, 35(4), 408-415. https://doi.org/10.1152/advan.00046.2011

Major, C. H., \& Palmer, B. (2001). Assessing the effectiveness of problem-based learning in higher education: Lessons from the literature. Academic Exchange Quarterly, 5(1), 4-9. http:// www.rapidintellect.com/AEQweb/mop4spr01.htm

McTaggart, R. (1994). Action research: A short modern history. Deakin University. 
Nuralam, N. (2009). Pemecahan masalah sebagai pendekatan dalam belajar matematika. Jurnal Edukasi, 5(1), 142-154.

Nurhadiyanto, D., \& Wagiran, W. (2007). Problem-based learning alternatif solusi dalam menyiapkan SDM holistik di SMK. Seminar Nasional Telisik Hambatan Pelaksanaan SMK Dan Solusinya, Jurusan Pendidikan Teknik Mesin UNNES, 1-14.

Partnership for 21st Century Skills. (2008). 21st Century skills, education \& competitiveness: A resource and policy guide. 21st Century Skills.

Regulation of the Minister of National Education of Republic of Indonesia No. 22 of 2006 on the Content Standard for Primary and Secondary Educational Units, (2006).

Rokhmawati, J. D., Djatmika, E. T., \& Wardana, L. (2016). Implementation of problem based learning model to improve students' problem solving skill and self-efficacy (A study on IX class students of SMP Muhammadiyah). IOSR Journal of Research \& Method in Education (IOSR-JRME), 6(3), 51-55. https://doi.org/10.9790/7388-0603045155

Sanjaya, W. (2009). Strategi pembelajaran berorientasi standar proses pendidikan. Kencana Prenada Media Group.

Selçuk, G. S., Çalişkan, S., \& Şahin, M. (2013). A comparison of achievement in problem-based, strategic and traditional learning classes in Physics. International Journal on New Trends in Education and Their Implications, 4(1), 154-164. http://ijonte.org/FileUpload/ks63207/File/ 14.selcuk.pdf

Simamora, R. E., Sidabutar, D. R., \& Surya, E. (2017). Improving learning activity and students' problem solving skill through Problem Based Learning (PBL) in junior high school. International Journal of Sciences: Basic and Applied Research, 33, 321-331.

Simamora, S. J., Simamora, R. E., \& Sinaga, B. (2017). Application of problem based learning to increase students' problem solving ability on Geometry in class X SMA Negeri 1 Pagaran. International Journal of Sciences: Basic and Applied Research (IJSBAR), 36(2), 234-251. https://www.gssrr.org/index.php/JournalOfBasicAndApplied/article/view/8100

Sofyan, H., Wagiran, W., \& Komariah, K. (2016). Problem based learning dalam implementasi Kurikulum 2013 di SMK. K-Media.

Sofyan, Herminarto, \& Komariah, K. (2016). Pembelajaran problem based learning dalam implementasi Kurikulum 2013 di SMK. Jurnal Pendidikan Vokasi, 6(3), 260-271. https:// doi.org/10.21831/jpv.v6i3.11275

Sudira, P. (2018). Metodologi pembelajaran vokasional abad XXI. UNY Press.

Susanti, H., Hobri, H., \& Susanto, S. (2016). How to improve students' creative thinking skills in learning Prism Nets through problem-based learning? International Journal of Scientific Research and Management, 5(8), 6789-6793. https://doi.org/10.18535/ijsrm/v5i8.28

Wagner, T. (2008). The global achievent gap. Basic Books.

Yeo, J., \& Tan, S. C. (2014). Redesigning problem-based learning in the knowledge creation paradigm for school science learning. Instructional Science, 42(5), 747-775. https://doi.org/ $10.1007 / \mathrm{s} 11251-014-9317-6$ 